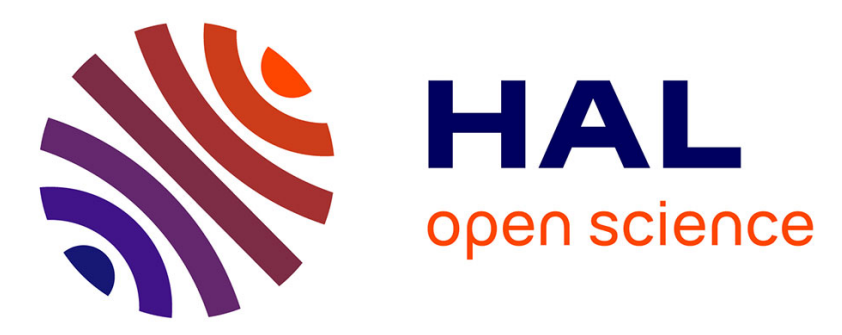

\title{
Study of lead phytoavailability for atmospheric industrial micronic and sub-micronic particles in relation with lead speciation
}

Gaëlle Uzu, Sophie Sobanska, Yassine Aliouane, Philippe Pradere, Camille Dumat

\section{To cite this version:}

Gaëlle Uzu, Sophie Sobanska, Yassine Aliouane, Philippe Pradere, Camille Dumat. Study of lead phytoavailability for atmospheric industrial micronic and sub-micronic particles in relation with lead speciation. Environmental Pollution, 2009, 157 (4), pp.1178-1185. 10.1016/j.envpol.2008.09.053 . hal-00559688

\section{HAL Id: hal-00559688 \\ https://hal.science/hal-00559688}

Submitted on 26 Jan 2011

HAL is a multi-disciplinary open access archive for the deposit and dissemination of scientific research documents, whether they are published or not. The documents may come from teaching and research institutions in France or abroad, or from public or private research centers.
L'archive ouverte pluridisciplinaire HAL, est destinée au dépôt et à la diffusion de documents scientifiques de niveau recherche, publiés ou non, émanant des établissements d'enseignement et de recherche français ou étrangers, des laboratoires publics ou privés. 
1 Study of lead phytoavailability for atmospheric industrial micronic and

2 submicronic particles in relation with lead speciation.

3

4 G. Uzu ${ }^{\mathrm{a}}$, S. Sobanska ${ }^{\mathrm{b}}, \mathrm{Y}$.Aliouane ${ }^{\mathrm{a}}$, P. Pradere ${ }^{\mathrm{c}}$ and C. Dumat ${ }^{\mathrm{a}}$

5 a-EcoLab UMR 5245 CNRS-INPT-UPS, ENSAT BP 32607 Auzeville Tolosane, 31326

6 Castanet Tolosan, France.

7 b-LASIR UMR 8516 - Université des Sciences et Technologies de Lille - Bâtiment C5 859655 Villeneuve d'Ascq Cedex, France.

9 c- Chemical Metal Treatment Company, STCM, 30-32 chemin de Fondeyre, 31200 10 Toulouse, France.

12 * Corresponding author: Camille Dumat. Tel.: 335621939 03; fax: 33562193901.

13 E-mail address: camille.dumat@ensat.fr.

14 gaelle.uzu@ensat.fr; Sophie.Sobanska@univ-lille1.fr; p.pradere@stc-metaux.com;

16 Capsule

17 The soil-lettuce lead transfer from atmospheric industrial sub-micronic and micronic 18 particles depends on particle size.

20 Abstract

21 Particles from channelled emissions of a battery recycling facility were size-segregated and investigated to correlate their speciation and morphology with their transfer towards

23 lettuce. Microculture experiments carried out with various calcareous soils spiked with

24 micronic and submicronic particles $\left(1650 \pm 20 \mathrm{mgPb}^{-1} \mathrm{~kg}^{-1}\right)$ highlighted a greater transfer 25 in soils mixed with the finest particles. According to XRD and Raman spectroscopy 26 results, the two fractions presented differences in the amount of minor lead compounds 
27 like carbonates, but their speciation was quite similar, in decreasing order of abundance:

$28 \mathrm{PbS}, \mathrm{PbSO}_{4}, \mathrm{PbSO}_{4} \cdot \mathrm{PbO}, \alpha-\mathrm{PbO}$ and $\mathrm{Pb}^{0}$. Morphology investigations revealed that

$29 \mathrm{PM}_{2.5}$ (i.e. Particulate Matter 2.5 composed of particles suspended in air with aerodynamic diameters of 2.5 micrometers or less) contained many $\mathrm{Pb}$ nano balls and nano crystals which could influence lead availability. The soil-plant transfer of lead was mainly influenced by size and was very well estimated by $0.01 \mathrm{M} \mathrm{CaCl}_{2}$ extraction.

34 Keywords: lead, $\mathrm{PM}_{2.5}$ and $\mathrm{PM}_{10}$, soil-lettuce transfer, phytoavailability.

\section{Introduction}

Due to its numerous past and present uses and high persistence, lead is a major environmental contaminant (Chen et al., 2006). Potentially toxic for living organisms even at low concentrations, lead constitutes a risk for humans who can absorb it in various ways (Canfield et al., 2003). In the context of contaminated gardens, elevated

41 lead intake by humans can be due to the consumption of crop plants grown on soils with relatively high plant-available metal concentrations, ingestion of contaminated soil, either accidentally or intentionally (pica), inhalation of soil particles and drinking water with high soluble concentrations of metals (Alexander et al., 2006). The total quantities of lead emitted in the environment by industries have decreased sharply in recent decades (Glorennec et al., 2007) and are strictly controlled in Europe nowadays. Lead was recently classified as a substance of very high concern in the European REACH law (Regulation EC 1907/2006 of the European Parliament and of the Council of 18

49 December 2006 concerning the Registration, Evaluation, Authorisation and Restriction

50 of Chemicals). However, particles enriched with lead are still generated especially by 
51 lead-recycling plants (Batonneau et al., 2004; Ohmsen, 2001) and constitue the main source of lead pollution for soils (Miquel, 2001; Donisa et al., 2000).

According to Zhang et al. (2005), emitted particles present a large granulometric spectrum in the atmosphere, but during the last decade the proportion of fine particle matter (PM) increased with the use of more effective filters in industry. Indeed $\mathrm{PM}_{10}$ are target species of the World Heath Organization (WHO, 2001) and the European Union Framework Directive on ambient air quality assessment (EU, 1999), due to their adverse effects on the environment and human health. While micrometric and submicrometric fractions contribute very little to ambient particle mass, they may occur in substantial number concentrations. Most of the studies dealing with the characterization of metal-enriched particles in the ambient air provide information on quantitative measurements for $\mathrm{PM}_{10}$ fractions (EU directives 96/62 and 99/30) and very few on the sub-micronic fraction (Lazaridis et al., 2002). The lack of knowledge regarding metal speciation in the industrial particles results mainly from a lack of analytical tools, both sensitive and specific to the size of the particles.

These fine particles are hihgly reactive due to their high specific area and can be transported over long distances in the troposphere (Barrie, 1992). They could therefore present a greater impact on the biosphere than coarse particles (Fernandez Espinosa, 2005). Ruby et al. (1992) concluded that the bioaccessibility of lead rises strongly in particles under $2.4 \mu \mathrm{m}$ size. But, the phytoavailability of lead in industrial particles as a function of their size and speciation have not been studied yet. In comparison with zinc, lead generally shows a relatively low mobility in soils (Dumat et al., 2006). It can however migrate through the soil with dissolved organic matter (Cecchi et al., 2008) or be mobilized by certain plants (Arshad et al., 2008). Moreover, carried from the air to 
75 the soils as fine particles, lead could be released more easily in soil solution

76 (Komarnicki, 2005).

We therefore focused our study on the links between soil-plant transfer of lead,

size and speciation of particles emitted by a lead recycling plant, currently the main source of atmospheric emissions (Cecchi et al., 2008). The objectives were the

80 following: (i) the elemental and molecular characterisation of micrometer and nanometer sized lead-rich particles and (ii) to study the influence of particle characteristics on lead soil-plant transfer.

The physico-chemical characterization of industrial $\mathrm{PM}_{10}$ and $\mathrm{PM}_{2.5}$ particles collected in the plant was investigated using both bulk and micro analysis techniques: (i) MEB-EDS to determine the morphology and chemistry on the scale of a particle

86 (Laskin et al., 2006; Choel et al., 2005); (ii) Raman microspectrometry to study particle speciation (Batonneau et al., 2004; 2006; Falgayrac et al., 2006; Sobanska et al., 2006). The transfer of lead from particles to the lettuce Lactuca sativa a widely grown garden vegetable was investigated in the laboratory: two different uncontaminated calcareous soils were spiked with $\mathrm{PM}_{10}$ and $\mathrm{PM}_{2.5}$ for soil-plant experiments with a biotest device

91 that enabled careful study of rhizosphere and roots in addition to the transfer to the shoots (Chaignon and Hinsinger, 2003). The study was finally completed by $\mathrm{CaCl}_{2}$ extraction experiments carried out according to Houba et al. (1996) to estimate lead

94 phyto-availability.

The hypothesis tested throughout all these experiments was that particle 96 characteristics have a significant influence on lead soil-plant transfer and translocation.

2. Materials and methods

2.1. Particle sampling and size separation. 
A secondary lead smelter which currently recycles batteries was chosen as a representative example of the smelter metal industry to develop a methodology aimed at

102 the risk assessment of industrial lead particles. The plant of the Chemical Metal

103 Treatment Company (STCM) is located in the urban area of Toulouse $\left(43^{\circ} 38^{\prime} 12^{\prime}\right.$ N,

$10401^{\circ} 25^{\prime} 34^{\prime \prime}$ E). According to the French authorities (DRIRE, 2007), $328 \mathrm{~kg}$ of Total

105 Suspended Particles (TSP) including $31 \mathrm{~kg}$ of lead were emitted by this factory in 2007.

106 Three sources of particles corresponding to the three work units involving 107 different steps in the process are identified in the plant: (i) the battery grinding unit

108 where battery components are separated under wet conditions (ii) the smelter where lead 109 pastes are processed in rotary furnaces at $1200^{\circ} \mathrm{C}$ and finally (iii) the refinery where

110 lead is purified from unwanted metals or enriched. The same process has been used for 111 thirty years in the plant. This study focuses on channeled emissions only generated by 112 the furnace unit, considering the transfer towards the biosphere. The particle collection, 113 performed three months after complete cleaning of the three work units (March, 12, 114 2007), is therefore representative of that emission period. Our aim was to characterize

115 the reactivity of the particles in relation with their previously determined speciation and 116 size, not to follow one specific parameter over time.

$117 \quad 1 \mathrm{~kg}$ of particles was collected in polyethylene bags from the air-sleeve filters of

118 the furnace, then sealed and transferred in sealed opaque containers for transport to the 119 laboratory. Samples were passed through a 2-mm stainless steel AFNOR sieve. Process 120 dust was stored in a cool $\left(4^{\circ} \mathrm{C}\right)$ dark place with Merck desiccant.

121 Because $80 \%$ of emitted particles were smaller than $10 \mu \mathrm{m}, \mathrm{PM}_{2.5}$ and $\mathrm{PM}_{10}$ were 122 size-segregated by artificial resuspension in a Teflon bag (Batonneau et al., 2004;

123 Young et al. 2002) and collected by impaction onto a $\mathrm{PM}_{10 / 2.5}$ Dekati inertial impactor.

124 The cascade impactor consists of two successive stages with aerodynamic cut-off 
125 diameters of 10 and $2.5 \mu \mathrm{m}$ when it operates at $10 \mathrm{~L} / \mathrm{min}$ airflow. $\mathrm{PM}_{10}$ present an

126 aerodynamic diameter between 2.5 and $10 \mu \mathrm{m}$, whereas the $\mathrm{PM}_{2.5}$ stage collects

127 particles $<2.5 \mu \mathrm{m}$.

128

129 2.2. Characterization of particles

130 Elemental total contents of the two size fractions were determined by ICP-OES (IRIS

131 Intrepid II XDL) after heated digestion with standard acid $\left(\mathrm{HNO}_{3}, \mathrm{HCl}\right.$ and $\mathrm{HF}$,

132 Suprapur, Merk) in a PTFE vessel. Levels of $\mathrm{C}, \mathrm{H}, \mathrm{S}$ and $\mathrm{O}$ were determined after

133 burning in an elemental analyser with coulometric-catharometric detection and IR.

134 X-ray diffraction patterns of $\mathrm{PM}_{10}$ and $\mathrm{PM}_{2.5}$ were recorded on an INEL

135 diffractometer equipped with a curved detector CPS 120 and $\mathrm{Co}(\mathrm{K} \alpha)$ radiation allowing

136 a $120^{\circ} / 2 \theta$ detection. Crystallized compounds were identified by comparison with the

137 diffraction patterns of the JCPDS database. The relative abundance of each crystallized

138 phase detected in samples was qualitatively estimated by using the relative intensity of

139 the strongest X-ray pattern peaks of each considered phase. It should be noticed that

140 only crystallized phases with an abundance superior to $5 \%$ in weight can be detected by

141 XRD.

142 Particles were characterized using complementary microscopy and imaging

143 techniques to determine elementary and molecular composition, size, morphology and

144 heterogeneity of the individual lead-rich particles.

145 X-ray elemental mapping and secondary images were obtained using an

146 Environmental Scanning Electron Microscope (ESEM) working in high-vacuum mode.

147 The Quanta 200 FEI instrument was equipped with an energy-dispersive X-ray (EDX)

148 detector. ESEM was operated at 10-25 kV. Particles were dispersed on carbon 
149 substrates and analysed without further preparation. Because of the ESEM

150 configuration, light element detection $(\mathrm{C}, \mathrm{N}$, and $\mathrm{O})$ was ambiguous.

151 Raman microspectrometric measurements were carried out with a LabRAM

152 confocal spectrometer (Jobin Yvon, Horiba Gr, France). The spot size of the laser

153 focused by a $100 \times$ objective (numerical aperture $(\mathrm{NA})=0.90$ ) was estimated to be $1 \mu \mathrm{m}^{2}$

154 in size. A liquid nitrogen-cooled CCD (Jobin-Yvon, 2048 pixels $\times 512$ pixels) was used

155 for detection. The Raman backscattering was excited at $632.8 \mathrm{~nm}$ provided by an

156 internal, air-cooled, linearly polarized helium-neon laser. The laser power delivered to

157 the sample was $8 \mathrm{~mW}$. The microscope stage was XY-motorized and computer-

158 controlled for point by point scanning with $0.1 \mu \mathrm{m}$ resolution, $1 \mu \mathrm{m}$ reproducibility and

$15990 \mathrm{~mm} \times 60 \mathrm{~mm}$ spatial range. The glass plate with the impacted particles was mounted

160 on the microscope stage without any further preparation. Data acquisition consisted in

161 recording many spectra in point-by-point scanning mode with $1 \mu \mathrm{m}$ as a minimum step,

162 one accumulation and $30 \mathrm{~s}$ spectrum acquisition time. For identification of Raman

163 spectra the experimental spectra were compared to reference spectra using Spectral

164 Library Search ID 301 software (Thermo Galactic).

2.3. Measure of soil-plant lead transfer performing microculture experiments

Lettuce was chosen because it is a common vegetable widely grown for human consumption and has recently been used by several authors for metal transfer studies

169 (Khan et al., 2007; Waisberg et al., 2004; Alexander et al., 2006). Moreover, lettuce is 170 often used around plants to estimate atmospheric pollution.

171 The biotest presented on figure 1 was first described by Niebes et al. (1993) and 172 then adapted by Chaignon and Hinsinger (2003). A small PVC cylinder (25 mm inner 173 diameter) was closed by a polyamide net (900 $\mu \mathrm{m}$ mesh) inserted into a larger cylinder, 
174 itself closed by a finer polyamide mesh (30 $\mu \mathrm{m}$, Fyltis/Nytel, Sefar filtration). A space

175 of $3 \mathrm{~mm}$ was left between the net and the finer mesh, where the roots could develop as a 176 mat.

177 Commercial lettuce seeds, "Batavia blonde dorée" cultivar, were surface sterilized with $1780.9 \% \mathrm{CaClO}$ for $15 \mathrm{~min}$ and rinsed with deionised water. Three seeds were sown in the 179 container on the surface of the coarser mesh.

180 Lettuces were first grown hydroponically for 21 days to obtain a large flat mass of roots 181 that fully covered the fine mesh.

182 The devices were placed on top of troughs containing an aerated complete nutrient 183 solution with the macroelements: $5 \mathrm{mM} \mathrm{KNO}_{3}, 5 \mathrm{mM} \mathrm{Ca}\left(\mathrm{NO}_{3}\right)_{2}, 2 \mathrm{mM} \mathrm{KH_{2 }} \mathrm{PO}_{4}$ and

$1841.5 \mathrm{mM} \mathrm{MgSO} 4$ and oligoelements: $9.11 \mu \mathrm{M} \quad \mathrm{MnSO}_{4}, 1.53 \mu \mathrm{M} \mathrm{ZnSO} 4,0.235 \mu \mathrm{M}$ $185 \mathrm{CuSO}_{4}, 24.05 \mu \mathrm{M} \mathrm{H}_{3} \mathrm{BO}_{3}, 0.1 \mu \mathrm{M} \mathrm{Na}_{2} \mathrm{MoO}_{4}$ and $268.6 \mu \mathrm{M} \mathrm{Fe} / \mathrm{EDT}$. The height of the 186 nutrient solution was adjusted daily to keep the fine mesh wet during the whole pre187 culture period. The experiment was conducted in a growth chamber (temperature $24 \pm$ $188 \quad 0.5{ }^{\circ} \mathrm{C} / 18 \pm 0.5^{\circ} \mathrm{C}$ day/night cycles; photoperiod $16 \mathrm{~h}$ under daylight fluorescent lamps 189 providing $400 \mu \mathrm{mol} . \mathrm{m}^{-2} \cdot \mathrm{s}^{-1}$ [Philips 600W, Eindhoven, Netherlands] and $8 \mathrm{~h}$ darkness; 190 relative humidity $70 \%)$.

191 Then, the second step involved an eight-day soil-plant contact period: five replicate 192 plants for each treatment were transferred onto the various soil samples.

193 Top soils of two calcic cambisol profiles (FAO, 1998) produced by quaternary 194 alluvial deposits, were sampled. These two calcareous soils (noted soil-1 and soil-2) 195 with various physicochemical properties (table 1) were chosen because that kind of soil 196 happens to be observed around several battery recycling plants. Moreover, if the lettuce 197 species could favor lead transfer, the choice of calcareous soils could reduce it. The 198 soils differ by texture, soil cultivation, organic matter (OM) and CEC: soil-1 was 
uncultivated loamy-sandy clay with $2 \%$ of OM and soil-2 was sandy-clayey loam under sunflowers with $1 \%$ of $\mathrm{OM}$ and a higher CEC.

These two soils were spiked with $\mathrm{PM}_{2.5}$ and $\mathrm{PM}_{10}$ up to $[\mathrm{Pb}]=1650 \pm 20 \mathrm{mg} \cdot \mathrm{kg}^{-1}$.

$60 \mathrm{mg}$ of particles were added per box containing $10 \mathrm{~g}$ of soil and were agitated for a day. Soils were turned over every fifteen days for four months. This long period was chosen to allow time for natural equilibration of the various sorption mechanisms in the soil (Alexander et al., 2006). The relatively high total lead soil concentration was chosen to be representative of a real soil pollution situation observed for atmospheric fallout from an STCM plant (Cecchi et al., 2008) and we wanted to be sure that enough lead was available for the plant in soil solution. Surveys of garden soils in several countries have shown wide ranges of concentrations of heavy metals. For example,

210 Culbard et al. (1988) found concentrations of up to $14,100 \mathrm{mg} \mathrm{Pb} \mathrm{kg}{ }^{-1}$. Some soils were

211 left without crops, to determine the $\mathrm{pH}$ possible variation due to soil solution influence.

212 During the growth, $\mathrm{pH}$ was measured daily and nutrient solution level was maintained 213 constant. pH of nutrient solution was 5.5 \pm 0.3 during the hydroponic and soil contact 214 phases.

215 This biotest device presents two main advantages: (i) the roots are physically separated 216 from the soil which enables total recovery of the shoots, roots and soil; (ii) the thickness 217 of the soil layer used enables it to be considered it as rhizosphere soil and provides enough rhizosphere material to evaluate root-induced changes in metal speciation.

Roots and aerial parts were collected and analysed separately after the soil plant contact period. Biomass was determined before oven-drying at $80^{\circ} \mathrm{C}$ for $48 \mathrm{H}$. Lead bound to the outer root cell walls, called $[\mathrm{Pb}]_{\text {adsorbed, }}$, was determined according to the method of acidic desorption as described by Ferrand et al. (2006): roots were shaken 
added to yield a final concentration of $0.01 \mathrm{M} \mathrm{HCl}$. After shaking for another $5 \mathrm{~min}$, the suspension was filtered through ashless paper. Then, plant roots and aerial parts were mineralized separately in a $1: 1$ mixture of $\mathrm{HNO}_{3}$ and $\mathrm{H}_{2} \mathrm{O}_{2}$ at $80^{\circ} \mathrm{C}$ for $4 \mathrm{~h}$. After filtration, the major and trace element concentrations were determined with an IRIS Intrepid II XDL ICP-OES. The concentration in roots after mineralization is considered as uptaken lead $\left([\mathrm{Pb}]_{\text {roots }}\right)$. The accuracy of the acidic digestion and analytical procedures was verified using the reference material Virginia tobacco leaves, CTAVTL-2, ICHTJ.

\subsection{Estimation of lead availability by $\mathrm{CaCl}_{2}$ extraction experiments}

For the determination of the phytoavailable fraction, according to Menzies et al. (2007) neutral salts extractants provide the most useful indication. The $0.01 \mathrm{M} \mathrm{CaCl}_{2}$ extraction procedure gives a good indication of lead phytoavailability (Meers et al., 2007). The $\mathrm{CaCl}_{2}$ procedure, first described by Houba, et al. (1996), was performed on the two contaminated soils and particle samples $\left(\mathrm{PM}_{10}\right.$ and $\left.\mathrm{PM}_{2.5}\right) .30 \mathrm{~mL}$ of $0.01 \mathrm{M}$ $\mathrm{CaCl}_{2}$ solution was mixed with $3 \mathrm{~g}$ of soil $(1: 10$ solid solution ratio) in $50 \mathrm{ml}$ polypropylene centrifugation tubes placed on a shaker table (Heidolph promax 1020) at 50 oscillations $/ \mathrm{min}$ for $2 \mathrm{~h}, 20^{\circ} \mathrm{C}$. After extraction, the tubes were centrifuged at 10,000 $\mathrm{g}$ for 30 min (Avanti 30 centrifuge Beckman). The supernatant liquid was then filtered $(0.22 \mu \mathrm{m})$, acidified to $2 \%$ with distilled $\mathrm{HNO}_{3}(15 \mathrm{M}$, suprapur $99.9 \%)$ and stored at $4^{\circ} \mathrm{C}$ before analysis. That $\mathrm{CaCl}_{2}$ extraction procedure was performed on particles, reference soils, and the two spiked soils before and after culture. Extracted metal concentrations were determined by an IRIS Intrepid II XDL/ Thermo Electron Corporation model ICP-AES Calibration used reference materials (ion 915 from National Water Research Institute, Canada). 
2.5. Statistical data treatment

The plant absorption and chemical extraction data obtained were subjected to analysis of variance (ANOVA) with one factor, using the software Statistica, Edition'98 (StatSoft Inc., Tulsa, OK, USA). For each bioassay, mean values with different letters represent a significant difference $(\mathrm{p}<0.05)$ as measured by the LSD Fisher test. Letters are reported on the figures and tables.

\section{Results}

3.1. $\mathrm{PM}_{10}$ and $\mathrm{PM}_{2.5}$ characterization:

Elemental concentrations in particles are shown in table 2. All results are given as

260 the mean of the three replicates for each sample $\left(\mathrm{PM}_{10}\right.$ and $\left.\mathrm{PM}_{2.5}\right)$ and standard 261 deviations never exceed 7\%. No significant difference except for $\mathrm{Fe}$ in the total

262 elemental concentrations was observed in relation with the size of the particle. Major 263 elements found in the samples were, by mass: $\mathrm{Pb}(27 \%), \mathrm{O}(15 \%)$ and $\mathrm{S}(7.5 \%)$ for both 264 fractions. High levels of $\mathrm{Na}(3-4 \%)$ were due to the industrial recycling process where

$265 \mathrm{Na}$ is used to lower the melting point of $\mathrm{Pb}$. Several other metals: $\mathrm{Cd}(2.5 \%), \mathrm{Zn}(0.5 \%)$, $266 \mathrm{Fe}(0.1-0.4 \%)$ and $\mathrm{Sb}(0.1 \%)$ are also present. The remaining elements to complete to $267 \quad 100 \%$ are expected to be chloride and other trace metals. XRD patterns of $\mathrm{PM}_{10}$ and $\mathrm{PM}_{2.5}$ provide identification of major crystallized

269 species in bulk samples. The results are presented in table 3. Particles are mainly 270 composed of metallic sulfides, sulfates, oxides and perchlorates. A significant amount 271 of $\mathrm{Na}_{2} \mathrm{SO}_{4}$ was found in $\mathrm{PM}_{10}$ samples. Regardless of the size, the major phases 272 identified were the same and one more Fe species was detected for $\mathrm{PM}_{2.5}$. 
The ESEM-EDX analysis provided the morphology and elemental composition of individual particles in the two size fractions. $\mathrm{PM}_{10}$ samples exhibited both particles with a size range between 2 and $10 \mu \mathrm{m}$ and large aggregates composed of many micron-sized particles without specific shapes (figure 2). The main elements detected by EDX in these aggregates were, by order of importance, $\mathrm{Pb}, \mathrm{S}, \mathrm{Cl}, \mathrm{Sn}, \mathrm{Na}$, and $\mathrm{Fe}$. The chemical complexity of aggregates did not allow the detection of minor elements. Elemental mapping recorded on $\mathrm{PM}_{10}$ showed the chemical heterogeneity of aggregates. $\mathrm{PM}_{2.5}$ samples are composed of fine aggregates of few submicronic particles exhibiting characteristic features i.e. needles $(<100 \mathrm{~nm})$, nano crystals $(<500 \mathrm{~nm})$, cubes $(\sim 300$ $\mathrm{nm})$ and balls $(\sim 500 \mathrm{~nm})$. Elemental analysis of particles showed that needles mainly contain $\mathrm{Pb}$ and $\mathrm{S}$, nano crystals are composed of $\mathrm{Pb}, \mathrm{S}$ and $\mathrm{Cl}$ while $\mathrm{Na}$ and $\mathrm{S}$ are detected in cubic particles. Compared to the $\mathrm{PM}_{10}$ sample, numerous $\mathrm{Pb}$ only-rich nanoballs were observed in $\mathrm{PM}_{2.5}$ (figure 2).

Raman microspectrometry combines the analytical capability of Raman spectroscopy to distinguish in situ a wide range of chemical substances in aerosols with the spatial resolution of a confocal optical microscope $\left(\sim 1 \mu \mathrm{m}^{3}\right)$ which enables

289 investigation of individual particles. The scanning of a large area of sample $\left(300 \mu \mathrm{m}^{2}\right)$

290 by automated analyses enables the analysis of a huge number of particles. The data treatment of all the spectra recorded in this area leads to the major and minor component identification. xPbO.PbSO 4 (x = 1,2,3), $\mathrm{PbSO}_{4}, \alpha-\mathrm{PbO}, \mathrm{PbCO}_{3}, \mathrm{Na}_{2} \mathrm{SO}_{4}$,

293 and $\mathrm{ZnSO}_{4}$ were identified in both $\mathrm{PM}_{10}$ and $\mathrm{PM}_{2.5}$ samples as major species. The laserdamaging effect generates complete and irreversible oxidation of $\mathrm{PbS}$ to $\mathrm{PbSO}_{4}$ as described previously (Batonneau et al., 2000). The Raman mapping of species within 296 particles exhibits a large heterogeneity of particle composition. A typical Raman image 297 of $\mathrm{PM}_{2.5}$ particles is shown in figure 3. A large number of particles are composed of 
298 lead sulphate and are agglomerated with other compounds such as sodium sulphate or

299 carbonates in both $\mathrm{PM}_{10}$ and $\mathrm{PM}_{2.5}$ size fractions. The results suggest that no significant

300 differences in lead speciation are observed in accordance with the particle size.

301 However, for the minor lead compounds (like carbonates) not exactly quantified by

302 XRD, differences in percentages between the two size fractions could exist.

304 3.2. Assessment of the available fraction with $\mathrm{CaCl}_{2}$ extraction

305 Figure 4A and 4B shows respectively total lead concentrations extracted by $\mathrm{CaCl}_{2}$

306 and percentages of extracted lead with $\mathrm{CaCl}_{2}$ (relative, with respect to total lead

307 concentrations in different subtracts) for various samples: the single particles, soil-1 and

308 spiked soil-1 before and after an eight-day exposure of Lactuca sativa.

309 Due to high levels of lead in particles $\left(330,000 \mathrm{mg} \cdot \mathrm{kg}^{-1}\right)$, maximum lead quantities were

310 extracted from $\mathrm{PM}_{10}$ and $\mathrm{PM}_{2.5}$. But, in comparison with total lead contents, lead in

311 uncultivated spiked soils was $0.2 \%$ exchangeable, while $\mathrm{PM}_{10-2.5}$ presented a $0.01 \%$

312 exchangeability. Reference soils were under ICP-OES limit detection. After culture, a

313 significantly greater lead quantity was extracted by $\mathrm{CaCl}_{2}$ for the soil spiked with the

314 finest $\mathrm{PM}_{2.5}$ fraction than in $\mathrm{PM}_{10}$. A 1 unit $\mathrm{pH}$ decrease was measured after plant-soil

315 contact while the $\mathrm{pH}$ values of the control soils (left without crops but with nutrient

316 solution influence) remained constant. Concerning $\mathrm{CaCl}_{2}$ extraction, no significant

317 differences were observed between the two particle sizes in the $\mathrm{PM}_{10-2.5}$ and spiked soil-

3181 before culture; The same trends described above for soil-1 were also observed for soil-

3192.

320

321 3.3. Influence of lead exposure on plant growth. 
322 Fresh biomass data are shown in figure 5. After eight days of soil-plant exposure, 323 biomasses for aerial parts grown on spiked soils were slightly lower than in the 324 respective unspiked soils. No significant biomass differences were observed among the two types of spiking $\left(\mathrm{PM}_{10-2.5}\right)$. In controls, fresh weights were approximately $18.5 \pm 2.5$

$326 \mathrm{~g}$ for aerial parts and $3.7 \pm 0.7 \mathrm{~g}$ for roots while in spiked soils, weights reached $12 \pm 4$

$327 \mathrm{~g}$ and $2.5 \pm 1 \mathrm{~g}$ respectively. This slight influence of lead on plant biomass could be due

328 to lead toxicity (Sharma \& Dubey, 2005) or water status (Parys et al., 1998).

\subsection{Absorption and adsorption of lead in the lettuce}

Figure 6 presents results of lead transfer from soil to the various compartments of

332 the plant (roots and shoots) and the distribution between adsorption (noted $[\mathrm{Pb}]_{\mathrm{adsorbed}}$ )

333 and absorption for roots $\left([\mathrm{Pb}]_{\text {roots }}\right)$ respectively described in the materials and method section as lead only adsorbed at the root surface and lead truly taken up by the plant. Measurements on the reference samples (Tobacco leaf VTL-2) validated the assay: the concentration found was $21.4 \pm 1.1 \mathrm{mg} \cdot \mathrm{kg}^{-1}$, for a certified value of $22.1 \pm 1.2 \mathrm{mg} \cdot \mathrm{kg}^{-1}$.

337 Several trends were observed dealing with the influence of the particle type, soil type 338 and lead location. For both soils, a significant increase of lead adsorption on roots, 339 absorption and translocation throughout the shoots was observed, when the finest 340 particles were added in comparison with the $\mathrm{PM}_{10}$. Global uptakes $\left([\mathrm{Pb}]_{\text {adsorbed }}+\right.$

$\left.341[\mathrm{~Pb}]_{\text {roots }},+[\mathrm{Pb}]_{\text {shoots }}\right)$ were greater for soil 1 than for soil 2 . The main lead fraction was

342 adsorbed on root membranes where concentrations were up to $985 \pm 147 . \mathrm{kg}^{-1}$ for $\mathrm{PM}_{10}$ 343 contaminated soils and up to $1281 \pm 195 \mathrm{mg} \cdot \mathrm{kg}^{-1}$ for $\mathrm{PM}_{2.5}$ contaminated soils. The soils 344 spiked with $\mathrm{PM}_{10}$ allowed a lead uptake of $230 \pm 24 \mathrm{mg} \cdot \mathrm{kg}^{-1}$ by roots and a translocation 345 to aerial parts of $7.7 \pm 2.7 \mathrm{mg} \cdot \mathrm{kg}^{-1}$. While in the $\mathrm{PM}_{2.5}$ spiked soils, root and shoot 346 concentrations reached $275 \pm 40 \mathrm{mg} \cdot \mathrm{kg}^{-1}$ and $12.19 \pm 3 \mathrm{mg} \cdot \mathrm{kg}^{-1}$ respectively. 
4. Discussion

(1) Influence of particle size on soil-plant transfer and lead translocation.

Whatever the soil, for a given total lead concentration (1650 mg Pb.kg-1 soil),

higher lead soil-plant transfer and translocation were observed for the finest particles.

Roots exposed to $\mathrm{PM}_{2.5}$ spiked soils allowed a $20 \%$ greater lead uptake and a $30 \%$ increase in adsorbed lead. Shoots presented a $60 \%$ increase in translocated lead in $\mathrm{PM}_{10}$ spiked soils. For the first time in industrial particles, the transfer of lead to the soil solution and its translocation throughout the plant is reported to increase as the particle size decreases.

Douay et al. (2006), measuring lead concentrations in lettuces in urban gardens

358 (1572 mg Pb.kg ${ }^{-1}$ ) observed a shoot concentration of $5 \mathrm{mg} \mathrm{Pb} \cdot \mathrm{kg}^{-1} \mathrm{DW}$. The soil to plant metal transfer measured in this study (for one week of lead exposure) was relatively high in comparison with previously reported data in publications dealing with vegetables (BAPPET, 2007), probably because of particle size, but also due to numerous factors that influence the soil-plant transfer of metals (Kabata-Pendias, 2004;

Dumat et al., $2001 \&$ 2006; Costa \& Morel, 1993; Oliver et al., 1994).

Root transfer factors (TF-roots) and shoot transfer factors (TF-shoots) were calculated as ratios between $[\mathrm{Pb}]_{\text {roots, }}[\mathrm{Pb}]_{\text {shoots }}$ with $[\mathrm{Pb}]_{\text {soil }}$. TFr ranged from 0.10 to 0.17 and TFs were between 0.005 and 0.007 (table 4). These relatively low values

367 illustrate the known low mobility and availability of lead and are comparable to Khan et 368 al.'s results (2008) reporting 0.15 for TFr and 0.07 for TFs. As transfer factors for 369 vegetables decrease with increasing levels of lead in the soil (Zheng et al., 2007; Wang et al., 2006), we therefore expected a greater influence of particle size on transfer with a lower total lead concentration in soil. 
According to Sobanska et al. (1999), lead smelter emissions contain $\mathrm{PbS}, \mathrm{PbSO}_{4}$, $\mathrm{PbSO}_{4} . \mathrm{PbO}, \mathrm{Pb}, \alpha-\mathrm{PbO}$ compounds and numerous nano balls were observed for $\mathrm{PM}_{2.5}$.

374 Dumat et al. (2001) and Cecchi et al. (2008) working on soils polluted by lead produced by industrial atmospheric fallout from smelters, concluded that lead chemical speciation strongly influences its bioavailability. The sequence of solubility constants from the

377 CHESS data base for the lead is the following: $\mathrm{PbCO}_{3}>\mathrm{PbSO}_{4}>\mathrm{PbO}>\mathrm{Pb}^{0}$. In water media and equilibrium conditions, lead carbonate and sulphate will be much more labile than $\mathrm{PbO}$ or $\mathrm{Pb}^{0}$ species. However, according to Birkefeld et al. (2006 \& 2007) which used an in-situ method to study dissolution and phase transformation of lead particles from a smelter in different soils, the sequence of solubility is strongly dependent on soil characteristics (like texture, $\mathrm{pH}$, lime amount...). They observed that $\mathrm{PbO}$ was rapidly covered by lead-hydroxy carbonates (hydrocerussite) in some soils while in other it was relatively stable. Moreover, according to the general review of Ruby et al. (1992), release of lead in the soil solution depends on particle size, speciation and soil geochemistry. In soil solution, ligands like fulvic acids or low weight organic acids excreted by roots can displace the equilibrium (Ferrand et al., 2006). Finally, as no significant difference among speciation forms was noticed between $\mathrm{PM}_{10}$ and $\mathrm{PM}_{2.5}$, all changes observed in reactivity were attributed to size differences. soil-1 than for soil-2. In comparison with soil-2, soil-1 has more clay, its CEC is higher and its level of lime is lower (see Table 1). According to Twining et al. (2004), we

393 could expect that lead transfer would be higher for soil-2. However, several hypotheses can explain the results observed: (i) the higher amount of carbonates present in the soilinfluence of soil organic matter on the transfer of metals (Yin et al., 2002; Inaba \& 
397 Takenaka, 2005); (iii) for the total lead concentration studied, the relatively high 398 quantity of lead could be available in the soil solution (due to high solubility of the fine 399 particles) reducing the influence of soil characteristics.

400 Total lead in the roots $\left([\mathrm{Pb}]_{\text {roots }}+[\mathrm{Pb}]_{\text {adsorbed }}\right)$ reached $1500 \mathrm{mgPb} / \mathrm{kg}$ dry weight.

401 Lead in roots was predominantly adsorbed onto the cell walls, $80 \%$ of the total lead in

402 roots, and depends on the nature of the particles used for exposure: the uptake was 403 greater for $\mathrm{PM}_{2.5}$ than $\mathrm{PM}_{10}$. According to Seregin et al. (2004), $\mathrm{Pb}^{2+}$ binds to the 404 carboxy groups at the root surface reducing the translocation rate of lead (Pendergrass et 405 al., 2006; Piechalak et al., 2002). To illustrate this phenomenon, the translocation 406 factors or shoot/root ratios calculated indicate the ability of plants to transport metals 407 from the roots toward the aerial parts (Ferrand et al., 2006): they ranged between 0.03 408 and 0.04 (table 4). But considering the lower biomasses in roots than in shoots, we can 409 also reason with lead quantities. Whatever the type of soil or spiking, the total lead 410 quantity in shoots $\left(\mathrm{Pb}_{\text {shoots }} \times\right.$ dry weight $)$ between 0.003 and $0.007 \mathrm{mg} \mathrm{Pb}$ translocated 411 which represents up to $33 \%\left(\mathrm{PM}_{2.5}\right)$ of the total lead uptake. This percentage is not 412 negligible with respect to risks concerning consumption of vegetables.

$414 \quad$ (2) Behaviour of lead in the rhizosphere and assessment of lead availability

415 Relatively high lead transfer was observed for the lettuce cultivated on the two 416 alkaline spiked calcareous soils. $\mathrm{PM}_{10-2.5}$ can therefore release lead in particular in the 417 rhizosphere of Lactuca sativa. The lead availability estimated by the $\mathrm{CaCl}_{2}$ procedure 418 was greater for soils spiked with the finest particles and for both soils it increased after 419 soil-plant contact: $[\mathrm{Pb}]_{\mathrm{CaCl}_{2}}$ in spiked soil with $\mathrm{PM}_{2.5}>[\mathrm{Pb}]_{\mathrm{CaCl} 2}$ in spiked soil with $420 \mathrm{PM}_{10}$. Under the root activity influence, the $\mathrm{CaCl}_{2}$ lead extracted from polluted soils 421 increased and a one-unit pH decrease in soil was measured. Lin et al. (2004) and Kidd 
and Monterroso (2005) also observed that exchangeable lead was much higher in the rhizosphere than in the bulk soil. Producing exudates, plants can modify metal speciation and behaviour in the rhizosphere (Lin et al., 2004; Laperche, 1997; Welch, 1995). This phenomenon has been particularly observed for calcareous soil by Chaignon and Hinsinger (2003). As pH influences metal solubility and transfer (Wang et al., 2006), the rhizosphere acidification could have displaced the equilibrium towards bicarbonates, which are less stable than carbonates (Sauvé et al., 1998). An effect of soil on particle solubility was also observed: particles present a $\mathrm{CaCl}_{2}$ exchangeability ten times lower than in spiked soil. Quantities extracted for particles were only up to $1.5 \%$ of the solution extraction. Mixed with soil for four months, particle solubility could therefore have changed.

In order to estimate the transfer of lead from polluted soils towards lettuce, relationships were sought between: lead mobilised by $\mathrm{CaCl}_{2}$ extraction performed on soils before culture and lead concentrations in lettuce (shoots and roots). Equations were obtained from 6 parameters (2 soils; uncontaminated, spiked with $\mathrm{PM}_{10}$ or $\mathrm{PM}_{2.5}$ ), and every condition was studied by 5 replicates finally involving 30 observations. Significant correlations were observed between lead concentrations in shoots (Equation 1 below, with $r^{2}=0.8$ ) or in roots (Equation 2 below, with $r^{2}=0.9$ ) and lead extracted by $\mathrm{CaCl}_{2}$.

Equation 1: $[\mathrm{Pb}]_{\text {shoots }}=2.11 \times[\mathrm{Pb}]_{\mathrm{CaCl} 2}+2.13 \mathrm{r}^{2}=0.797 \mathrm{p}<0.01 \mathrm{n}=30$

Equation 2: $[\mathrm{Pb}]_{\mathrm{roots}}=35.02 \times[\mathrm{Pb}]_{\mathrm{CaCl} 2}+4.24 \mathrm{r}^{2}=0.915 \mathrm{p}<0.005 \mathrm{n}=30$

Both for $\mathrm{PM}_{10}$ and $\mathrm{PM}_{2.5}$, the $\mathrm{CaCl}_{2}$ chemical extraction was therefore a good indicator of soil-plant transfer. As previously shown by Pueyo et al. (2004), the $0.01 \mathrm{~mol}^{-1}$ $\mathrm{CaCl}_{2}$ extraction procedure seems to be a suitable method for the determination of phytoavailable lead. This test simplifies the matrix and could avoid in vivo tests. 


\section{Conclusions and perspectives}

449 A significant size influence was found for soil-plant lead transfer and translocation

450 throughout the lettuce when micronic and nanometric industrial particles were 451 compared: roots exposed to $\mathrm{PM}_{2.5}$ spiked soils allowed a $20 \%$ greater lead uptake and a $45230 \%$ increase in adsorbed lead. Shoots presented a $60 \%$ increase in translocated lead in $453 \mathrm{PM}_{10}$ spiked soils. Our results highlight that source characteristics strongly influence 454 metal transfer: total metal soil concentration is insufficient to estimate the risk induced 455 by soils polluted by metals. Lead speciation was quite similar in $\mathrm{PM}_{10}$ and $\mathrm{PM}_{2.5}$ 456 particles i;e. $\mathrm{PbS}, \mathrm{PbO} \mathrm{PbSO}_{4}, \mathrm{PbO}, \mathrm{PbCO}_{3}$ and $\mathrm{Pb}^{0}$, were predominant however 457 differences could exist for minor lead components. Moreover, the high amount of $\mathrm{Pb}-$ 458 rich nano balls and nano crystals much more dispersed for $\mathrm{PM}_{2.5}$ could influence the 459 lead transfer in the rhizoshere acidified by plant root activity. Lead concentrations in the 460 edible part of lettuces were very well estimated by $0.01 \mathrm{M} \mathrm{CaCl}_{2}$ extraction.

461 In order to check the generality of the size influence of industrial particles on soil462 plant transfer, further experiments could be performed on other vegetables and various 463 soils testing aging effects. Moreover, the study of other metals and metalloids measured 464 in the particles will be performed.

\section{Acknowledgements}

467 ADEME, the French Agency for Environment and Energy as well as the STCM, are 468 gratefully acknowledged for their financial support and technical help. This research 469 project was supported by the National CNRS CYTRIX-EC2CO program. We thank Dr

470 J. Silvestre from ENSAT for cropping advice, P. Recourt from Laboratoire

471 Geosystèmes, UMR CNRS 8157, University of Lille for ESEM-EDX measurements and 
J. Laureyns from LASIR UMR CNRS 8516, for Raman Microspectrometry assistance.

473 Finally, Dr P. Winterton from UPS is acknowledged for English review.

474

475

\section{References}

Alexander, P. D., Alloway, B. J. \& Dourado, A. M., 2006. Genotypic variations in

477 the accumulation of $\mathrm{Cd}, \mathrm{Cu}, \mathrm{Pb}$ and $\mathrm{Zn}$ exhibited by six commonly grown vegetables.

478 Environmental Pollution 144(3), 736-745.

479

Arshad, M., Silvestre, J., Pinelli, E., Kallerhoff, J., Kaemmerer, M., Shahid, M.,

Pradere, P. \& Dumat, C., 2008. A field study of lead phytoextraction by various scented

Pelargonium cultivars. Chemosphere 71, 2187-2192.

Bahemuka, T. E. \& Mubofu, E.B., 1999. Heavy metals in edible green vegetables grown along the sites of the Sinza and Msimbazi rivers in Dar es Salaam, Tanzania. Food Chemistry 66(1), 63-66.

BAPPET -Database on ETM in vegetables. ADEME, INERIS, CNAM, INP,

ENSAT,ISA.2008.http://www.sitespollues.ecologie.gouv.fr/DocumentsDiagnostics.asp

\#BAPPET.

Barrie, L. A., 1992. Scavenging Ratios: Black Magic or Useful Scientific Tool?, in

S. E. Schwartzand W. G. N. Slinn (eds), Precipitation Scavenging and Atmosphere-

492 Maguer, D., Perdrix, E., and Sobanska S., 2004. Speciation of $\mathrm{PM}_{10}$ sources of airborne 493 nonferrous metals within the 3-km zone of lead/zinc smelters. Environ. Sci. Technol. 494 $38,5281-5289$. 
Batonneau, Y., Sobanska, S., Laureyns, J., Bremard, C., 2006. Confocal microprobe raman imaging of urban tropospheric aerosol particles. Environ. Sci. Technol. 40, 1300-1306. imaging Raman scattering study of $\mathrm{PbS}$ and its photo-oxidation products. Journal of

500 Raman Spectroscopy 31, 1113-1119.

501 Birkefeld, A., Schulin, R.,Nowack, B., 2007. In situ transformations of fine lead oxide particles indifferent soils. Environ. Pollut. 145: 554-561.

504 of heavy metal containing mineral particles in an acidic forest soil. Geochim.

505 Cosmochim. Acta. 70: 2726-2736.

506 Canfield, R.L., Henderson, C.R., Jr., Cory-Slechta, D.A., Cox, C.,. Jusko, T.A and 507 Lanphear, B.P., 2003. Intellectual impairment in children with blood lead concentrations below $10 \mu \mathrm{g}$ per deciliter. N. Engl. J. Med. 348, 1517-1526. Multi-metal contamination of a calcic cambisol by fallout from a lead-recycling plant.

511 Geoderma 144, 287-298. to plants in a contaminated soil. J Environ Qual 32, 824-833.

514 Chen, Y., Wang, C., Wang, Z., 2005. Residues and source identification of

515 persistent organic pollutants in farmland soils irrigated by effluents from biological 516 treatment plants. Environ. Int. 31, 778-783.

Choel, M.; Deboudt, K.; Osan, J.; Flament, P.; Van Grieken, R., 2005. 
519 substrates by automated scanning electron microscopy-energy-dispersive X-ray

520 Spectrometry Anal. Chem. 77(17), 5686-5692.

Choël, M., Deboudt, K., Flament, P., Lecornet, G., Perdrix, E., Sobanska, S.,

2006. Fast evolution of tropospheric $\mathrm{Pb}$ - and $\mathrm{Zn}$-rich particles in the vicinity of a lead smelter. Atmospheric Environment 40, 4439-4449.

Costa, G., Morel, J.L., 1993. Cadmium uptake by Lupinus albus (L.): cadmium

excretion, a possible mechanism of cadmium tolerance. Journal of plant nutrition (USA) 16(10), 1921-1929.

Culbard, E.B., Thornton, I., Watt, J., Wheatley, M., Moorcroft, S., Thompson, M.,

1988. Metal contamination in British suburban dusts and soils. Journal of

Environmental Quality 17, 226-234.

530 Donisa, C., Mocanu, R., Steinnes, E. And Vasu, A., 2000. Heavy Metal Pollution

by Atmospheric Transport in Natural Soils from the Northern Part of Eastern

Mahieu, A.L., 2005. Cadmium, lead and zinc concentrations in soil and vegetables from

kitchen gardens in urban and highly-contaminated areas of northern France: evaluation

of the risk of population exposure, ConSoil 2005. Proceedings of the 9th International

FZK/TNO Conference on Soil-Water Systems. Bordeaux, France (2005), 667-676.

http://www.midi-pyrenees.drire.gouv.fr/

540 Dumat, C., Chiquet, A., Gooddy, D., Aubry, E., Morin, G., Juillot, F., Benedetti,

541 M.F., 2001. Metal ion geochemistry in smelter impacted soils and soil solutions.

542 Bulletin De La Societe Geologique De France 172, 539-548. 
Dumat, C., Quenea, K., Bermond, A., Toinen, S., Benedetti, M.F., 2006. Study of

544 the trace metal ion influence on the turnover of soil organic matter in cultivated contaminated soils. Environmental Pollution 142, 521-529.

Ebert, M., Inerle-Hof, M. and Weinbruch, S., 2002. Environmental scanning

547 electron microscopy as a new technique to determine the hygroscopic behaviour of

548 individual aerosol particles. Atmospheric Environment 36, 5909-5916.

549 European Commission, 96/62/CE directive (September 27, 1996) for the quality of ambient air; directive 22/04/99 setting maximum levels for lead in ambiant air; REACH directive Regulation (EC) No 1907/20061, Directive 67/548/EEC.

Falgayrac, G., Sobanska, S., Laureyns, J., Brémard, C., 2006. Heterogeneous chemistry between $\mathrm{PbSO}_{4}$ and calcite microparticles using Raman microimaging. Spectrochimica Acta Part A: Molecular and Biomolecular Spectroscopy 64, 1095-1101.

FAO, 1998. World reference base for soil research. World Soil resources Report, v. 84. FAO, Rome.

Fernandez Espinosa, A.J.,Rossini Oliva, S., 2006. The composition and relationships between trace element levels in inhalable atmospheric particles $\left(\mathrm{PM}_{10}\right)$ and

559 in leaves of Nerium oleander L. and Lantana camara L. Chemosphere 62, 1665-1672.

560 Ferrand, E., Dumat, C., Leclerc-Cessac, E., Benedetti, M.F., 2006. 561 Phytoavailability of zirconium in relation to its initial added form and soil 562 characteristics. Plant and Soil 287, 313-325.

563 Glorennec , P., Bemrah, N.,Tard,A., Robin, A., Le Bot, B., Bard, D., 2007. 564 Probabilistic modeling of young children's overall lead exposure in France: Integrated approach for various exposure media. Environment International 33, 937-945. 
Houba, V.J.G., Lexmond, T.M., Novozamsky, I., van der Lee, J.J., 1996. State of

the art and future developments in soil analysis for bioavailability assessment. Science of The Total Environment 178, 21-28.

Inaba, S., Takenaka, C., 2005. Effects of dissolved organic matter on toxicity and

bioavailability of copper for lettuce sprouts. Environment International, 31, 603-608.

Kabata-Pendias, A., 2004. Soil-plant transfer of trace elements an environmental issue. Geoderma 122, 143-149.

Khan, S., Aijun, L., Zhang, S.Z., Hu, Q.H., Zhu, Y.G., 2008. Accumulation of 506-515.

Kidd, P.S., Monterroso, C., 2005. Metal extraction by Alyssum serpyllifolium ssp. lusitanicum on mine-spoil soils from Spain. Science of The Total Environment 336, 111.

Komarnicki, G.J.K., 2005. Lead and cadmium in indoor air and the urban environment. Environmental Pollution 136, 47-61. amendments on plant uptake of lead from contaminated soil. Environ. Sci. Technol. 31, $2745-2753$. particles using modern methods of electron microscopy and X-ray microanalysis.

587 Journal of Electron Spectroscopy and Related Phenomena 150, 260-274. 
590 determining the relationship between emissions and observed concentration levels. The

591 science of the total environment 285, 209-235.

592

Lin, Q., Chen, Y.X., He, Y.F., Tian, G.M., 2004. Root-induced changes of lead availability in the rhizosphere of Oryza sativa L. Agriculture, Ecosystems \&

594 Environment 104, 605-613.

Meers, E., Samson, R., Tack, F.M.G., Ruttens, A., Vandegehuchte, M.,

Vangronsveld, J., Verloo, M.G., 2007. Phytoavailability assessment of heavy metals in

soils by single extractions and accumulation by Phaseolus vulgaris. Environmental and Experimental Botany 60, 385-396.

Menzies, N.W., Donn, M.J., Kopittke, P.M., 2007. Evaluation of extractants for

600 estimation of the phytoavailable trace metals in soils. Environmental Pollution 145, $601 \quad 121-130$.

Miquel, G., 2001. Les effets des métaux lourds sur l'environnement et la santé. Rapport parlementaire européen.

Ohmsen, G. S., 2001.Characterization of fugitive material within a primary lead smelter. J. Air Waste Manage.Assoc. 51, 1443-1451.

Oliver, D.P., Hannam, R., Tiller, K.G., Wilhelm, N.S., Merry, R.H. and Cozens, G.D., 1994. The effects of zinc fertilization on cadmium concentration in wheat grain. J. Environ. Qual. 23, 705-711.

610 lead on photosynthesis and respiration in detached leaves and in mesophyll protoplasts

611 of Pisum sativum. Acta Physiologiae Plantarum 20(3), 313-322.

612 Pendergrass, A., Butcher, D.J., 2006. Uptake of lead and arsenic in food plants 613 grown in contaminated soil from Barber Orchard, NC. Microchemical Journal 83, 1461416. 
Piechalak, A., Tomaszewska, B., Baralkiewicz, D., Malecka, A., 2002.

616 Accumulation and detoxification of lead ions in legumes. Phytochemistry 60, 153-162. and $\mathrm{NH}_{4} \mathrm{NO}_{3}$ extraction procedures for the study of $\mathrm{Cd}, \mathrm{Cu}, \mathrm{Pb}$ and $\mathrm{Zn}$ extractability in contaminated soils. Analytica Chimica Acta 504, 217-226.

Ruby, M.V., Davis,A.,Kempton, J.H., Drexler, J.W., Bergstrom, P.D., 1992. Lead

Bioavailability: Dissolution Kinetics under Simulated Gastric Conditions. Environ. Sci. Technol. 26, 1242-1248.

D.E., Casteel, S.W., Berti, W., Carpenter, M., Edwards, D., Cragin, D., Chappell, W., 1999. Advances in evaluating the oral bioavailability of inorganics in soil for use in human health risk assessment. Environ. Sci. Technol. 33, 3697-3705.

Sauvé, S., Dumestre, A., McBride, M., Hendershot, W., 1998. Derivation of soil Toxicology and Chemistry 17(8), 1481-1489.

Seregin, I.V., Kozhevnikova, A.D., 2004. Strontium transport, distribution, and toxic effects on maize seedling growth. Russian Journal of Plant Physiology 51, 215632 221.

635 Sobanska, S., Ricq, N., Laboudigue, A., Guillermo, R., Bremard, C., Laureyns, J., 636 Merlin, J.C., Wignacourt, J.P., 1999. Microchemical investigations of dust emitted by a 637 lead smelter. Environ. Sci. Technol. 33, 1334-1339. 
Sobanska S., Pauwels B., Maenhaut W. and Adams F., 2002. Single particle characterisation and sources of tropospheric aerosols in the Negev desert (Israel). Journal de Physique IV 12(Pr10), 161-183. of individual aerosol particle using multivariate curve resolution of confocal Raman 643 image. Spectrochim Acta A Mol Biomol Spectrosc. 64, pp. 1102-1109.

644 Twining, J.R., Payne, T.E., Itakura T., 2004. Soil-water distribution coefficients and plant transfer factors for ${ }^{134} \mathrm{Cs},{ }^{85} \mathrm{Sr}$ and ${ }^{65} \mathrm{Zn}$ under filed conditions in tropical Australia. J Environ Radioac 71, 71-87.

Waisberg, M., Black, W.D., Waisberg, C.M., Hale, B., 2004. The effect of pH, 648 time and dietary source of cadmium on the bioaccessibility and adsorption of cadmium 649 to/from lettuce (Lactuca sativa L. cv. Ostinata). Food and Chemical Toxicology 42, 650 $835-842$. characteristics of cadmium and lead from soil to the edible parts of six vegetable species in southeastern China. Environmental Pollution 144, 127-135.

Welch, R.M., 1995. Micronutrient nutrition of plants. Critical Reviews in Plants Sciences $14,49-82$.

WHO, 1987. Air quality guidelines for Europe. WHO Regional Publications,

657 European Series No. 23.

658 Yin, Y., Impellitteri, C.A., You, S.J., Allen, H.E., 2002. The importance of 659 organic matter distribution and exact soil : solution ratio on the desorption of heavy 660 metals from soils. The Science of the Total Environment 287, 107-119. 
662 soil as a source of airborne lead near industrial facilities and highways. Environ. Sci. 663 Technol. 36, 2484-2490.

664 Zhang Z., C. Kleinstreuer, J.F. Donohuec, C.S. Kim., 2005. Comparison of micro665 and nano-size particle depositions in a human upper airway model. J Aerosol Science $66636,211-233$.

667 Zheng, N., Wang, Q., Zheng, D., 2007. Health risk of $\mathrm{Hg}, \mathrm{Pb}, \mathrm{Cd}, \mathrm{Zn}$, and $\mathrm{Cu}$ to 668 the inhabitants around Huludao Zinc Plant in China via consumption of vegetables. 669 Science of The Total Environment 383, 81-89.

670

671

672 
$675 \quad$ Figure 1

676 Microculture device.

677

\section{Figure 2}

679 ESEM images of $\mathrm{PM}_{2.5}(\mathrm{~A})$ and $\mathrm{PM}_{10}(\mathrm{~B})$.

680

\section{$681 \quad$ Figure 3}

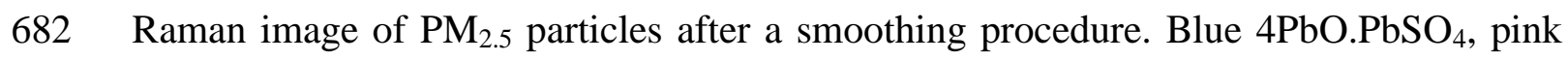
$683 \mathrm{PbO} \mathrm{PbSO}_{4}$, red $\mathrm{Na}_{2} \mathrm{SO}_{4}$ and green substrate.

684

685

Figure 4

686 Total contents (A) and relative contents (B) of lead extracted with $\mathrm{CaCl}_{2}$ on particles 687 (white), spiked soils with lead particles of different size before (grey) and after (black) a 688 seven-days exposure of Lactuca sativa, $\mathrm{n}=5$.

689

$690 \quad$ Figure 5

691 Plant biomass data for aerial parts (black) and roots (grey). The error bars indicate the 692 standard deviation while different letters show significant differences $(\mathrm{p}<0.05)$ as 693 measured by an LSD fisher test (one-factor ANOVA ).

694

$695 \quad$ Figure 6

696 Lead concentrations in different plant compartments: A: adsorbed onto roots, B: root 697 uptake and C: translocated in shoots. 


\section{Table 1}

700 Physico-chemical characteristics of the two soils used for micro-culture experiments.

\begin{tabular}{|c|c|c|c|}
\hline & unit & Soil-1 & Soil-2 \\
\hline pH & & 8.3 & 8.4 \\
\hline CEC & $\mathrm{cmol}+/ \mathrm{kg}$ & 19.9 & 8.9 \\
\hline Clay & \multirow{3}{*}{$\left(\right.$ g. $\left.\mathrm{kg}^{-1}\right)$} & 405 & 195 \\
\hline Silt & & 261 & 390 \\
\hline Sand & & 334 & 415 \\
\hline $\mathbf{C} / \mathbf{N}$ & & 9.15 & 8.9 \\
\hline MO & $\left(\right.$ g. $\left.\mathrm{kg}^{-1}\right)$ & 18.8 & 12.5 \\
\hline Total carbonates & $\left(\right.$ g. $\left.\mathrm{kg}^{-1}\right)$ & 36.8 & 98 \\
\hline $\mathbf{P}_{2} \mathbf{O}_{5}$ Joret Hebert & $\left(\right.$ g. $\left.\mathrm{kg}^{-1}\right)$ & 0.28 & 0.215 \\
\hline Cd (HF extraction) & \multirow{4}{*}{$\left(\mathrm{mg} \cdot \mathrm{kg}^{-1}\right)$} & 0.22 & 0.175 \\
\hline $\mathbf{P b}(\mathrm{HF})$ & & 35.5 & 21 \\
\hline$\overline{Z n}(\mathbf{H F})$ & & 101 & 48 \\
\hline $\mathrm{Cu}(\mathrm{HF})$ & & 28.5 & 31 \\
\hline
\end{tabular}

701

702

703

704 
705 Table 2

706 Total elemental analysis of particles.

\begin{tabular}{ccccccccccccccc}
\hline & \multicolumn{11}{c}{ Contents $\left(\mathbf{m g . k g}^{-\mathbf{1}}\right) \pm \mathbf{7 \%}$} \\
\cline { 2 - 14 } Sample & Al & As & Cd & $\mathrm{Cu}$ & $\mathrm{Fe}$ & $\mathrm{O}$ & $\mathrm{Na}$ & $\mathrm{Ni}$ & $\mathrm{Pb}$ & $\mathrm{Sb}$ & $\mathrm{Zn}$ & $\mathrm{S}$ & $\mathrm{C}$ \\
\hline $\mathbf{P M}_{2,5}$ & 10 & 867 & 25243 & 480 & 1395 & 149300 & 31691 & 41 & 272834 & 1266 & 5194 & 78100 & 12100 \\
$\mathbf{P M}_{10}$ & 52 & 841 & 23139 & 617 & 4010 & 150000 & 39697 & 97 & 267353 & 1361 & 5372 & 74300 & 11500 \\
\hline
\end{tabular}

707

708

709 
$710 \quad$ Table 3

711 Determination of main chemical speciation of lead in the $\mathrm{PM}_{10}$ and $\mathrm{PM}_{2.5}$ particles by

712 X-Ray Powder Diffraction Analysis ${ }^{a}$

\begin{tabular}{c|cc}
\hline Sample & Cristallized compound & Estimated \% of phases \\
\hline $\mathrm{PM}_{10}$ & $\mathbf{P b S}$, & 55 \\
& PbO.PbSO$_{4}, \mathbf{P b S O}_{4}, \mathrm{~Pb}\left(\mathrm{ClO}_{4}\right)_{2}, \mathrm{~Pb}$, & 25 \\
& $\mathbf{N a}_{2} \mathbf{S O}_{4}$ & 10 \\
& $\mathrm{CdS}, \mathrm{Cd}\left(\mathrm{ClO}_{4}\right)_{2}, \mathrm{ZnO}, \mathrm{ZnSO}_{4}$ & 55 \\
\hline $\mathrm{PM}_{2,5}$ & $\mathbf{P b S}$, & 25 \\
& $\mathbf{P b O}_{4}, \mathbf{P b S O}_{4}, \mathrm{~Pb}\left(\mathrm{ClO}_{4}\right)_{2}, \mathrm{~Pb}$, & 10 \\
& $\mathbf{N a}_{2} \mathbf{S O}_{4}$ & 10 \\
& $\mathrm{CdS}, \mathrm{Cd}\left(\mathrm{ClO}_{4}\right)_{2}, \mathrm{ZnO}, \mathrm{ZnSO}_{4}, \mathrm{FeS}_{2}$ & \\
\hline
\end{tabular}

713

$714^{a}$ The major compounds are written in bold

715

716

717

718 
719 Table 4

720 Tranfer factors in roots (TFr) and shoots (TFs) and translocation ratios.

\begin{tabular}{cccc}
\hline Soil & TFs & TFr & Translocation \\
\hline S1 + PM10 & 0.005 & 0.14 & 0.03 \\
S1 + PM $_{2.5}$ & 0.007 & 0.17 & 0.04 \\
S1 & 0.081 & 0.26 & 0.31 \\
S2 + PM10 & 0.004 & 0.10 & 0.04 \\
S2 + PM 2.5 & 0.005 & 0.15 & 0.03 \\
S2 & 0.01 & 0.44 & 0.18 \\
\hline
\end{tabular}

721

722

723 
726

727

728

729

730

731

732

733

734

735

736

737

738

739

740

741

742

743

744

745

746

747

748 


\section{Figure 2}

750

(A)

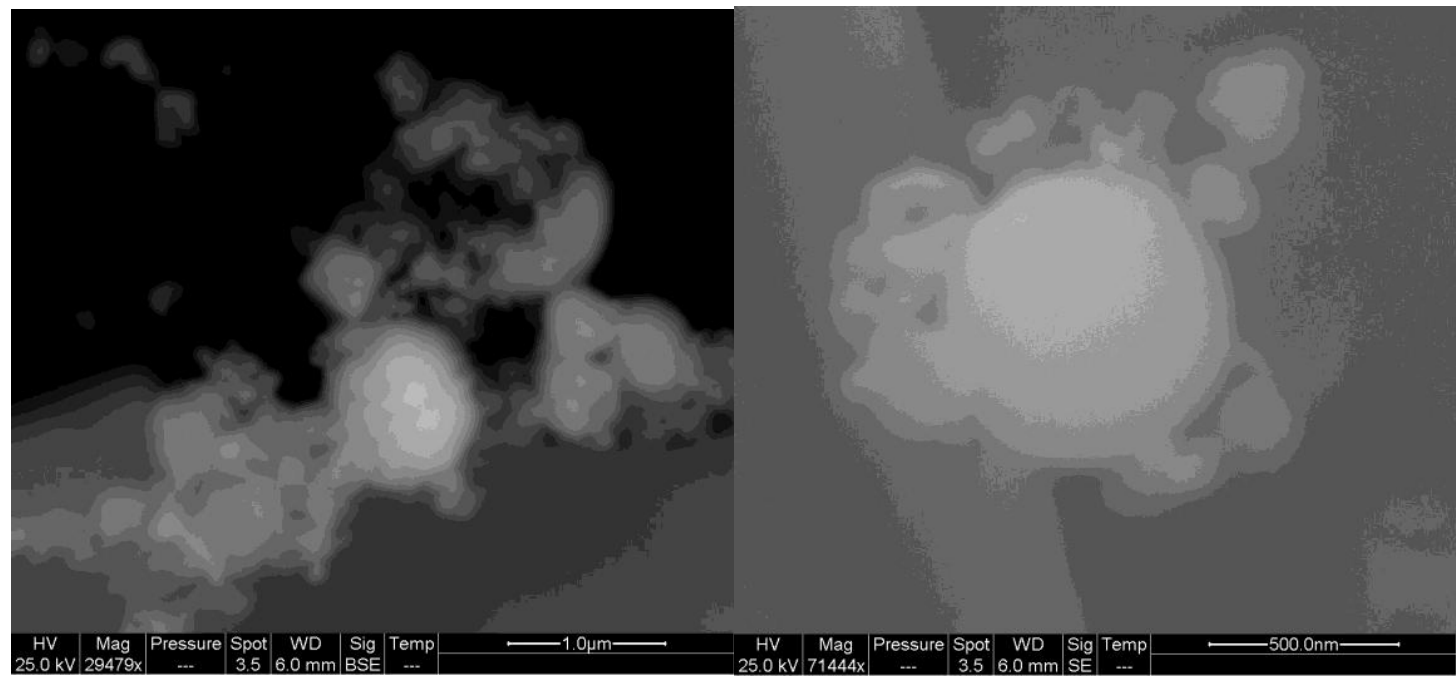

752

(B)

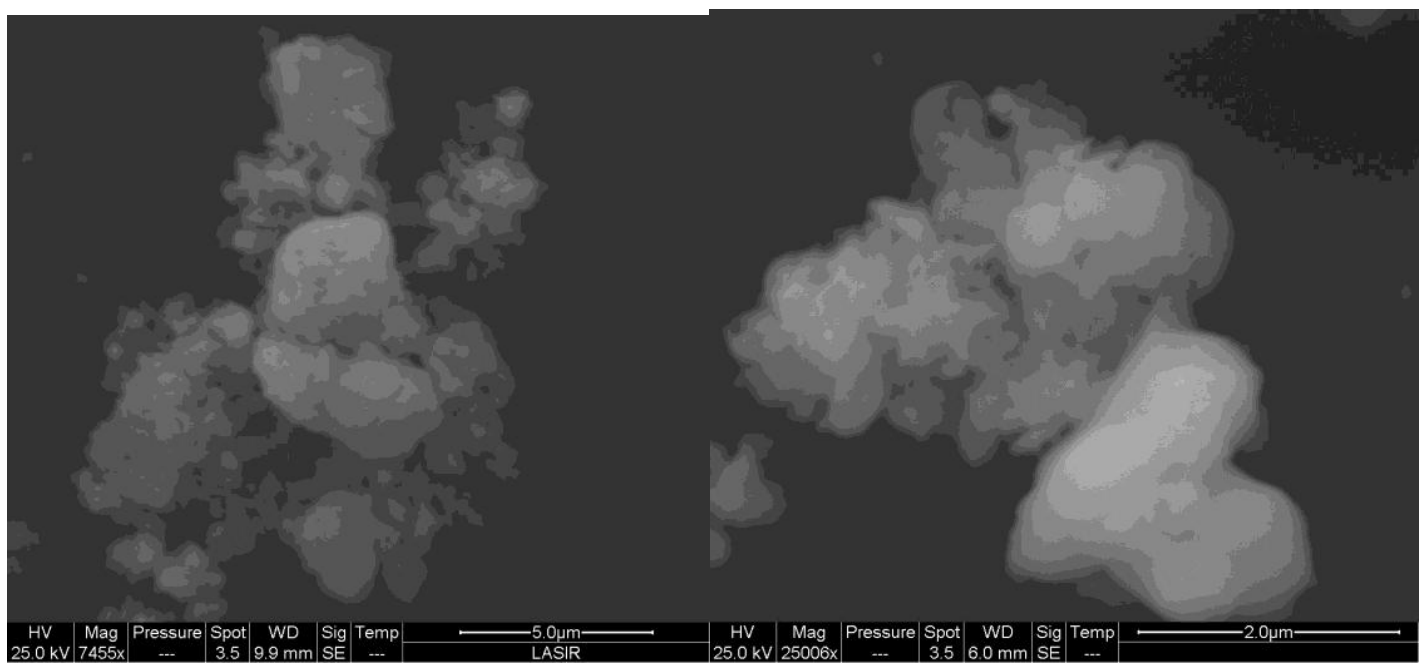




\section{Figure 3}

762

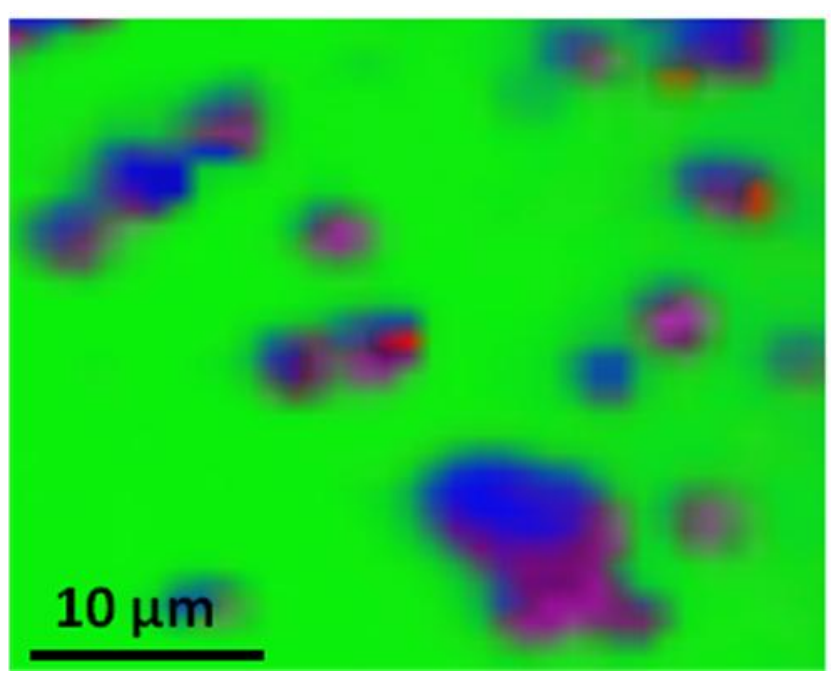

763 


\section{Figure 4}

765

(A)

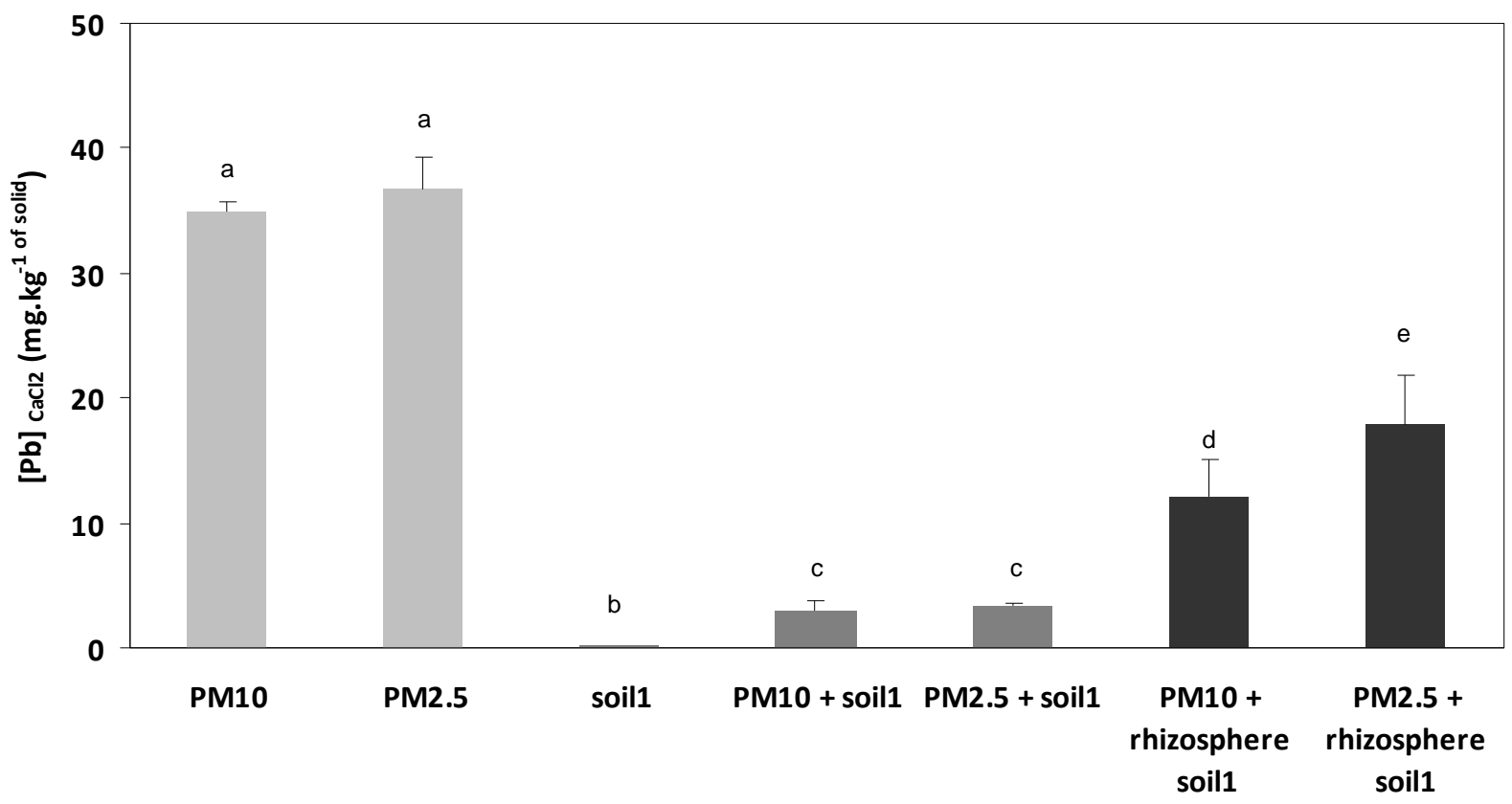

766

(B)

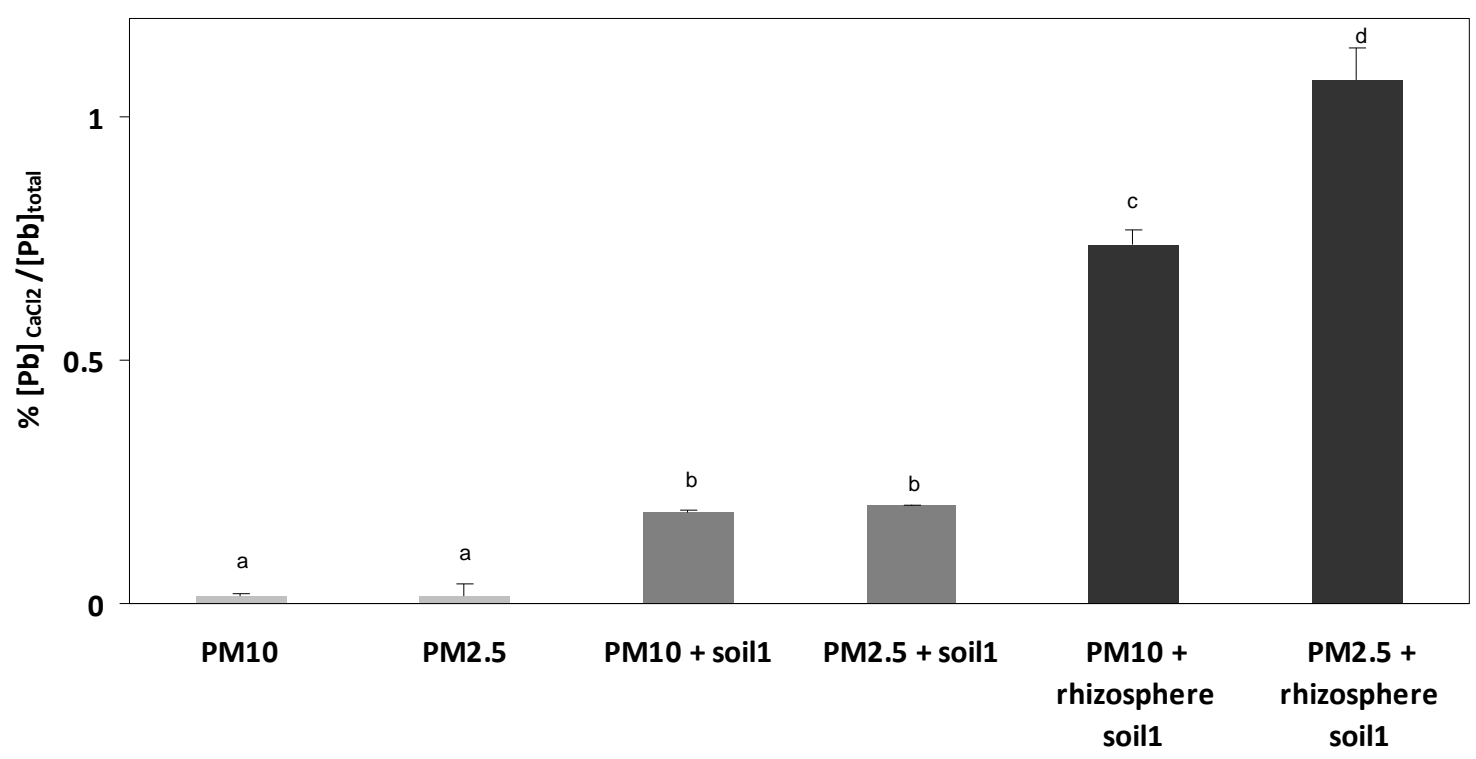


Figure 5

772

773

774

775

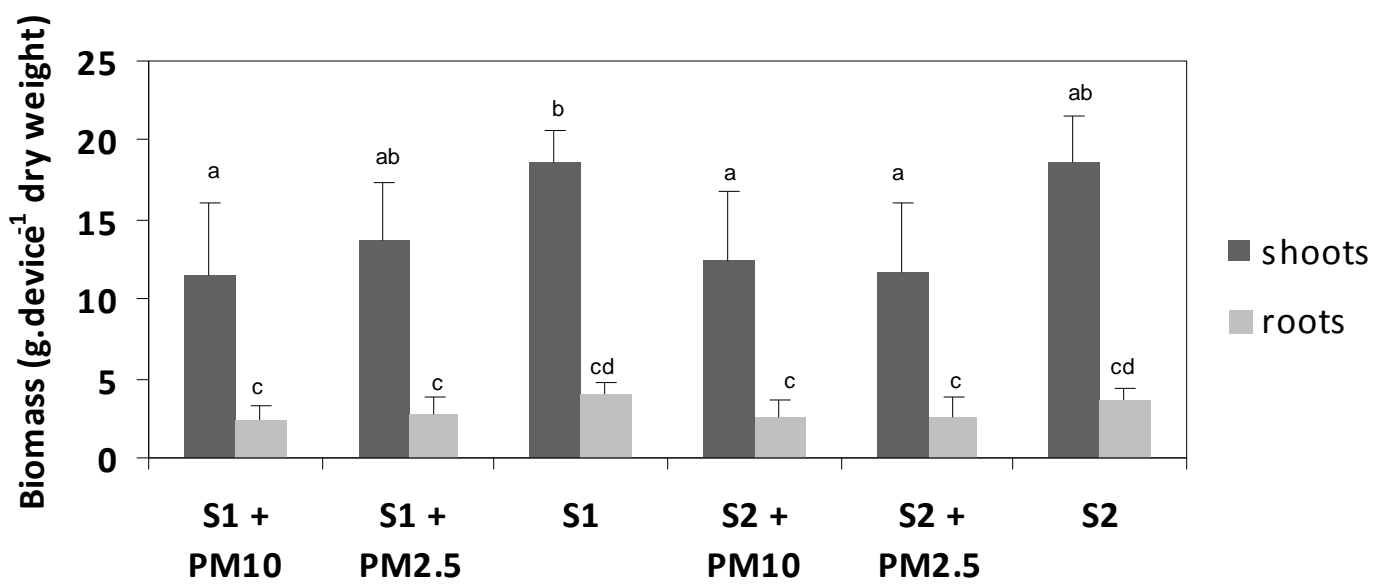


778

779

780

781

782

783

784

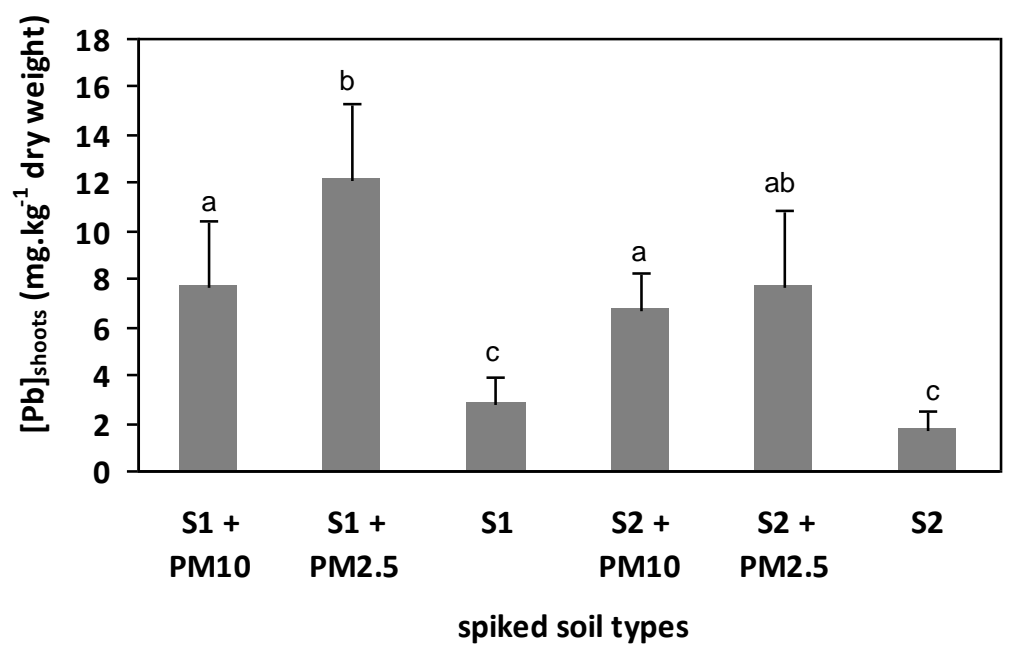

786

(B)

787

788

789

790

791

792

793

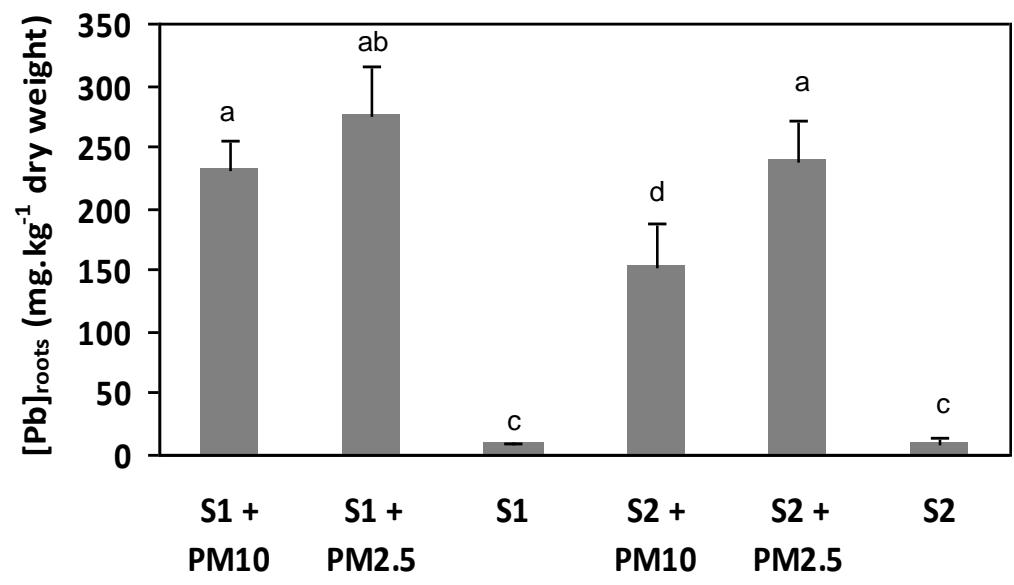

794

spiked soil types

795

(C)

796

797

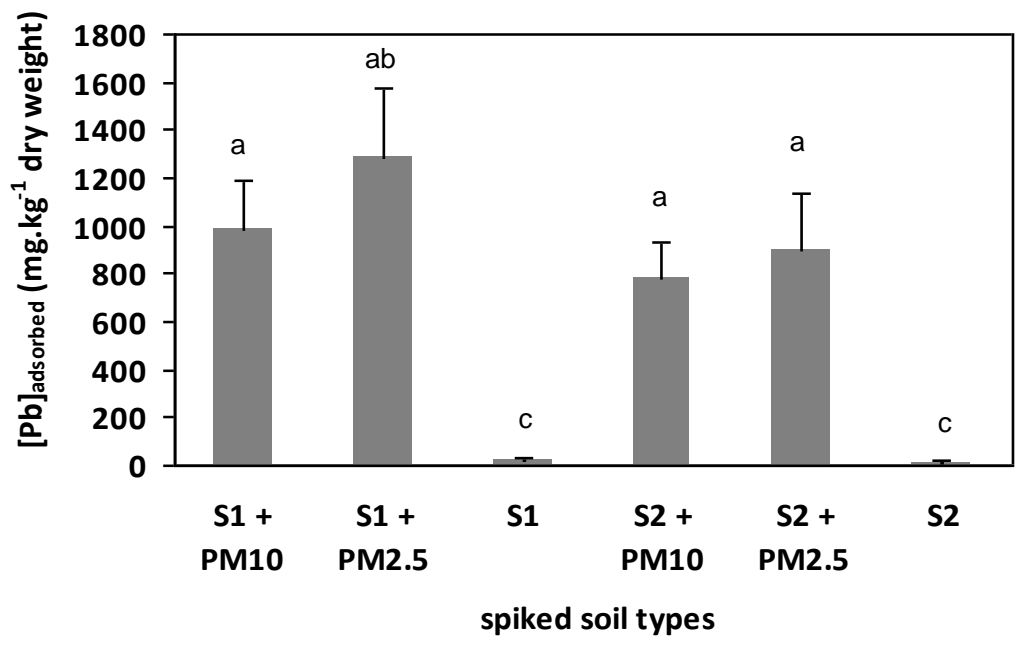

